\title{
Using jasmonates and salicylates to reduce losses within the fruit supply chain
}

\author{
Marcin Glowacz*, Deborah Rees \\ Natural Resources Institute, University of Greenwich, Chatham, ME4 4TB, United Kingdom \\ *Corresponding author. Tel.: +44 (0) 1634883564 \\ E-mail address: M.M.Glowacz@greenwich.ac.uk
}

\begin{abstract}
The fresh produce industry is constantly growing, due to increasing consumer demand. The shelf-life of some fruit, however, is relatively short, limited by microbial contamination or visual, textural and nutritional quality loss. Thus, techniques for reducing undesired microbial contamination, spoilage and decay, as well as maintaining product's visual, textural and nutritional quality are in high demand at all steps within the supply chain. The postharvest use of signalling molecules, i.e. jasmonates and salicylates seems to have unexplored potential. The focus of this review is on the effects of treatment with jasmonates and salicylates on the fresh produce quality, defined by decay incidence and severity, chilling injury, maintenance of texture, visual quality, taste and aroma, and nutritional content. Postharvest treatments with jasmonates and salicylates have the ability to reduce decay by increasing fruit resistance to diseases and reducing chilling injury in numerous products. These treatments also possess the ability to improve other quality characteristics, i.e. appearance, texture maintenance and nutritional content. Furthermore, they can easily be combined with other treatments, e.g. heat treatment, ultrasound treatment. A good understanding of all the benefits and limitations related to the postharvest use of jasmonates and salicylates is needed, and relevant information has been reviewed in this paper.
\end{abstract}

\section{Keywords:}

Jasmonates

Salicylates

Fresh produce

Quality and safety

Sensory evaluation

Storage 


\section{Introduction}

Fresh produce has been recognised as a healthy food, thus there is increasing consumer demand for fresh fruit and vegetables. In 2013, the fruit and vegetables market in the UK was valued at nearly $£ 2.0$ billion [Basic Horticultural Statistics, DEFRA, 2014 (https://www.gov.uk/)], where home production, as a \% of total supply, was above $50 \%$ for vegetables, and only around $10 \%$ for fruit. This means that a substantial quantity of fresh produce, especially fruit being sold in the UK comes from overseas.

The storability of fruit is often limited and determined by the initial quality at harvest and subsequent storage conditions [1]. The quality of fresh produce may be reduced during transit and subsequent storage due to increased microbial contamination, visual and textural changes, or reduced nutritional value. The difficulties of maintaining quality of fruit, compared to other commodities is greater due to the challenge of controlling the physiological processes of ripening; in some cases allowing them to proceed so that the fruit becomes more acceptable to the consumer, and in some cases slowing them down to prevent quality loss. Thus, there is a need for new techniques to reduce undesired microbial contamination, spoilage and decay, as well as maintain product's visual, textural and nutritional quality. There are a number of chemical and physical methods used to reduce microorganisms present on fresh produce and extend its storage life, e.g. the use of chlorine, hydrogen peroxide, organic acids, UV radiation [2], ozone [3, 4], various antimicrobials and anti-browning agents [5]. Other compounds, on the other hand, e.g. 1-methylcyclopropene (1-MCP), an inhibitor of ethylene perception $[6,7]$, may be beneficial to some products by affecting their ripening process and physiology. The postharvest use of signalling molecules, for example jasmonates and salicylates, however, seems to have unexplored potential.

In recent years, there has been an increasing interest in using jasmonates [8-10] and salicylates [11-14] owing to their potential to reduce chilling injury, i.e. pitting, discolouration and susceptibility to decay [15] and in this way extend the shelf-life of fresh produce. These treatments can be applied either as a vapour, where the initial concentration of the solution (often spotted onto filter paper inside the container) is given and time allowing the methyl jasmonate/methyl salicylate to evaporate is specified [16-18]. They can also be used as dips $[19,20]$ when prepared in aqueous solution, where dose equals to concentration $\mathrm{x}$ time of treatment. A good understanding of all the benefits and limitations related to the use of these chemicals is needed and this review aims to collate the latest findings. The effects of postharvest treatments of fruit with jasmonates (jasmonic acid (JA), methyl jasmonate (MeJA)) and salicylates (salicylic acid (SA), methyl salicylate (MeSA)) on produce quality defined by disease incidence and severity, maintenance of texture, visual quality, flavour and nutritional 
content will be discussed. The purpose of this review is to evaluate the practical potential of jasmonates and salicylates as a strategy to improve postharvest handling of fruit. Therefore the phenomenological effects are described but the review does not seek to completely explain the complex biology or how these signalling compounds interact with other plant hormones, except where this improves the understanding of how to exploit them practically.

\section{Physiological effects}

\section{Respiration}

Quality loss during the storage of fresh produce may be accelerated by changes in the metabolic activity of the product. Respiration rate (consumption of $\mathrm{O}_{2}$ and production of $\mathrm{CO}_{2}$ ), is a good measure of physiological activity, since it increases with tissue damage and deterioration [21]. A number of studies have found reduced respiration rate in produce treated with jasmonates and salicylates, e.g. in loquat treated with MeJA at $10 \mu \mathrm{mol} \mathrm{l}^{-}$

${ }^{1}$ for $24 \mathrm{~h}$, stored at $1^{\circ} \mathrm{C}$ [17], in strawberries treated with MeJA at $100 \mu \mathrm{mol} \mathrm{l} \mathrm{l}^{-1}$, stored at $7.5^{\circ} \mathrm{C}$ [22], in banana dipped in SA at 500 and $1000 \mu \mathrm{mol} \mathrm{l} \mathrm{l}^{-1}$ for $6 \mathrm{~h}$ [23], Qingnai plums dipped in SA at $1500 \mu \mathrm{mol} \mathrm{l} \mathrm{l}^{-1}$ for $10 \mathrm{~min}$, stored at $1^{\circ} \mathrm{C}$ [24], in custard apples dipped in SA at 400, 800 and $1200 \mu \mathrm{mol} \mathrm{l}^{-1}$ for $15 \mathrm{~min}$, stored at $15^{\circ} \mathrm{C}$ [25]. Reduced respiration rate was also observed in pomegranates dipped in acetyl salicylic acid (ASA - a close analogue of salicylic acid) at 100,500 and $1000 \mu \mathrm{mol} \mathrm{l}^{-1}$ for $10 \mathrm{~min}$, stored at $2^{\circ} \mathrm{C}$ [13]. The positive effects were associated with either reduced chilling injury in MeJA treated loquat [16], SA treated plums [24] and pomegranates [13] or delayed ripening observed in SA treated banana [23] and custard apples [25].

Several studies, on the other hand, found no difference in the respiration rate between treated and untreated fruit, e.g. in mangos treated with MeJA at $100 \mu \mathrm{mol} \mathrm{l} \mathrm{l}^{-1}$ for 24 hours, subsequently stored at $7^{\circ} \mathrm{C}$ [26], in papaya treated with MeJA at 10 and $100 \mu \mathrm{mol} \mathrm{l}{ }^{-1}$, stored at $10^{\circ} \mathrm{C}$ [27] and raspberries treated with MeJA at $100 \mu \mathrm{mol} \mathrm{l} \mathrm{l}^{-1}$, stored at $10{ }^{\circ} \mathrm{C}[28]$.

The response of the produce was found to depend not only on the concentration used but also on the stage of development of the fruit [29]. Ding and Wang [29] observed that respiration rate and ethylene production were increased in tomato fruit at green mature stage treated with MeSA at $100 \mu \mathrm{mol} \mathrm{l}^{-1}$ for $16 \mathrm{~h}$ and stored at $20^{\circ} \mathrm{C}$, which would suggest that MeSA treatment at $100 \mu \mathrm{mol} \mathrm{l}^{-1}$ stimulated fruit ripening. In contrast, respiration rate and ethylene production were reduced in tomato fruit at breaker and turning stage treated with MeSA at 100 $\mu \mathrm{mol} \mathrm{l}^{-1}$ and in tomatoes at all three developmental stages, green mature, breaker and turning stage, treated with MeSA at $500 \mu \mathrm{mol} \mathrm{l}{ }^{-1}$, where ripening of the fruit was delayed or inhibited. Respiration rate and ethylene

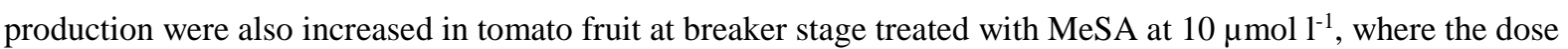


was probably too low to limit ethylene production. Breaker stage maturity is the time when increase in the production of ethylene is usually observed [30, 31]. The findings of Ding and Wang [29] confirmed that SA has the ability to reduce ethylene production [32] and delay ripening. A similar observation has been reported in kiwi dipped in ASA at $1000 \mu \mathrm{mol} \mathrm{l} \mathrm{l}^{-1}$ for $5 \mathrm{~min}$ [33, 34], in strawberries, treated with SA at 1000-4000 $\mu \mathrm{mol} \mathrm{l}^{-1}$ [35], in custard apples dipped in SA at 400, 800 and $1200 \mu \mathrm{mol} \mathrm{l}^{-1}$ for $15 \mathrm{~min}$ [25]. It has been reported [29, 33] that treatment with ASA suppresses the activity of ACC (aminocyclopropanecarboxylate) oxidase and ACC synthase, reducing conversion of ACC to ethylene. More recently Yin et al. [34] highlighted that ASA may not only affect ethylene biosynthesis but it may also interfere with its perception. The data highlight the fact that the concentration of SA has to be properly adjusted, i.e. be high enough to interfere with the ripening process, since lower concentrations may actually increase ethylene production [29].

\section{Weight loss}

Several studies have reported reduced weight loss in fresh produce treated with jasmonates or salicylates prior to storage, e.g. in loquat treated with $16 \mu \mathrm{mol} \mathrm{l} \mathrm{l}^{-1} \mathrm{MeJA}$ for $6 \mathrm{~h}$ and subsequently stored at $1{ }^{\circ} \mathrm{C}$ [36], in peaches dipped in SA at 500-2000 $\mu \mathrm{mol} \mathrm{l}^{-1}$ for $5 \mathrm{~min}$, stored at $0{ }^{\circ} \mathrm{C}$ [37], in strawberries dipped in SA at $2000 \mu \mathrm{mol} \mathrm{l}^{-1}$ for $15 \mathrm{~min}$, stored at $2{ }^{\circ} \mathrm{C}$ [38], and sweet peppers dipped in SA at 1000-4000 $\mu \mathrm{mol} \mathrm{l}^{-1}$ for $15 \mathrm{~min}$, stored at 10 or $25^{\circ} \mathrm{C}$ [39].

On the other hand, weight loss was not affected in mangos treated with MeJA at $100 \mu \mathrm{mol} \mathrm{l} \mathrm{l}^{-1}$ for $24 \mathrm{~h}$, stored at $7{ }^{\circ} \mathrm{C}$ [26] or treated with MeJA at 10 and $100 \mu \mathrm{mol} \mathrm{l}^{-1}$ for $20 \mathrm{~h}$, stored at 5 or $10^{\circ} \mathrm{C}$ [40], in papaya treated with MeJA at 10 and $100 \mu \mathrm{mol} \mathrm{l}{ }^{-1}$ for $16 \mathrm{~h}$, stored at $10^{\circ} \mathrm{C}$ [27], and in tomatoes treated with MeJA at $200 \mu \mathrm{mol}$ $\mathrm{l}^{-1}$, stored at $13^{\circ} \mathrm{C}$ [41]. Weight loss, however, was significantly reduced in mangos [26, 40] and papaya [27] treated with MeJA at 10 and $100 \mu \mathrm{mol} \mathrm{l}{ }^{-1}$ during their shelf-life period, i.e. when fruit were subsequently transferred to $20^{\circ} \mathrm{C}$, especially in those treated with MeJA at $100 \mu \mathrm{mol} \mathrm{l}^{-1}$. Interestingly, weight loss was reduced in mangos treated with $\mathrm{MeJA}$ at $10 \mu \mathrm{mol} \mathrm{l}{ }^{-1}$ stored at $20^{\circ} \mathrm{C}$ immediately after the treatment, but not in

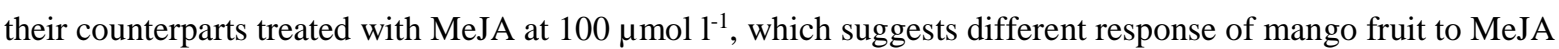
treatment during storage at higher temperature, where weight loss is accelerated [40]. It is clear that in some of the studies mentioned above, positive effect of the treatment was due to reduced chilling injury, while in other cases it was associated with lower respiration resulting in delayed deterioration. 


\section{Texture}

Jasmonates and salicylates slow softening in a wide range of non-climacteric and climacteric fruit

Texture loss during storage is a serious problem for fresh produce industry because it reduces marketability of the product. A number of authors have studied the effect of jasmonates and salicylates on firmness maintenance during storage. The treatment of banana with SA at 500 and $1000 \mu \mathrm{mol} \mathrm{l} \mathrm{l}^{-1}$ for $6 \mathrm{~h}$ resulted in reduced softening during subsequent storage [23]. Similarly, softening was reduced in kiwi dipped in ASA at $1000 \mu \mathrm{mol} \mathrm{l}^{-1}$ for 5 $\min [33,34]$.

Texture maintenance was improved in cherries dipped in SA and ASA at $1000 \mu \mathrm{mol} \mathrm{l}^{-1}$ for $10 \mathrm{~min}$ stored at $2{ }^{\circ} \mathrm{C}$ [42], in custard apples dipped in SA at 400, 800 and $1200 \mu \mathrm{mol} \mathrm{l}{ }^{-1}$ for 15 min stored at $15^{\circ} \mathrm{C}$ [25], and bell peppers dipped in SA at $1000-4000 \mu \mathrm{mol} \mathrm{l}^{-1}$ for 15 min stored at 10 or $25^{\circ} \mathrm{C}$ [39], which was associated with delayed ripening. Loss of firmness was also reduced in papaya treated with MeJA at 10 and 100 $\mu \mathrm{mol} \mathrm{l}^{-1}$ and stored at $10{ }^{\circ} \mathrm{C}$ [27], and pomegranates treated with ASA at 100, 500 and $1000 \mu \mathrm{mol} \mathrm{l^{-1 }}$ for 10 min [13] or with MeJA or MeSA at 10 and $100 \mu \mathrm{mol} \mathrm{l} \mathrm{l}^{-1}$ for $16 \mathrm{~h}$ [12] stored at $2^{\circ} \mathrm{C}$, due to reduced chilling injury. Finally, firmness was improved in strawberries dipped in SA at $2000 \mu \mathrm{mol} \mathrm{l} \mathrm{l}^{-1}$ for 15 min and stored at $2{ }^{\circ} \mathrm{C}$ [38], where decay was reduced when compared with untreated samples.

Firmness was not affected in mangos treated with MeJA at $100 \mu \mathrm{mol} \mathrm{l}^{-1}$ for $24 \mathrm{~h}$ and stored at $7^{\circ} \mathrm{C}$ [26], at 10 and $100 \mu \mathrm{mol} \mathrm{l} \mathrm{l}^{-1}$ for $20 \mathrm{~h}$, stored at $5^{\circ} \mathrm{C}$ [40], or at $10 \mu \mathrm{mol} \mathrm{l}{ }^{-1}$, stored at $10{ }^{\circ} \mathrm{C}$, while in mangos treated with MeJA at $100 \mu \mathrm{mol} \mathrm{l}^{-1}$ and stored at $10{ }^{\circ} \mathrm{C}$ firmness was reduced [40]. The firmness of mangos treated with MeJA at $10 \mu \mathrm{mol} \mathrm{l}{ }^{-1}$ stored at $10{ }^{\circ} \mathrm{C}$, however, was better maintained compared with untreated ones, when they were subsequently transferred to $20^{\circ} \mathrm{C}$. Firmness was also not affected in mangos dipped in SA at $2000 \mu \mathrm{mol} \mathrm{l} \mathrm{l}^{-1}$ for $10 \mathrm{~min}$, stored at $5^{\circ} \mathrm{C}[43]$ but was reduced in mangos treated with MeSA at $100 \mu \mathrm{mol} \mathrm{l}^{-1}$ for $12 \mathrm{~h}$ stored at $5^{\circ} \mathrm{C}[44]$, due to SA effect on ethylene production.

Firmness was not affected in tomatoes dipped in MeJA at $100 \mu \mathrm{mol} \mathrm{l} \mathrm{l}^{-1}$ for 15 min stored at 10 and 20 ${ }^{\circ} \mathrm{C}$ [45] or treated with MeJA vapour at $200 \mu \mathrm{mol} \mathrm{l}{ }^{-1}$ stored at $13^{\circ} \mathrm{C}$ [41], and pears treated with MeJA at 200 $\mu \mathrm{mol} \mathrm{l} \mathrm{l}^{-1}$, stored at 4 and $20^{\circ} \mathrm{C}[46]$.

Meng et al. [8] observed better firmness maintenance in peaches treated with MeJA at $100 \mu \mathrm{mol} \mathrm{l}^{-1}$ for $12 \mathrm{~h}$ and stored at $5{ }^{\circ} \mathrm{C}$, for up to 3 weeks. This effect, however, was lost when peaches were transferred for 3 days of shelf-life at $20^{\circ} \mathrm{C}$. Similar findings have been reported in peaches treated with MeJA at $1 \mu$ mol l-1 for 24 h, stored at $0{ }^{\circ} \mathrm{C}[47,48]$. Interestingly, the firmness of peaches was higher in fruit treated for 5 min with SA at 
$1000 \mu \mathrm{mol} \mathrm{l}^{-1}$ [49] and at 500-2000 $\mu \mathrm{mol} \mathrm{l}^{-1}$ [37] stored at $0^{\circ} \mathrm{C}$; texture maintenance was improved at higher doses of SA [37], which might be related to reduced chilling injury and ethylene production.

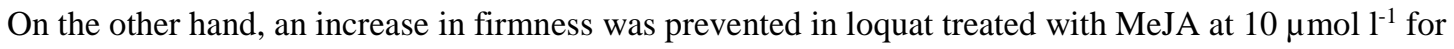
$24 \mathrm{~h}[11,16,50]$ or $16 \mu \mathrm{mol} \mathrm{l}^{-1}$ for $6 \mathrm{~h}$ [36]. A similar response was observed in loquat fruit dipped in ASA at $1000 \mu \mathrm{mol} \mathrm{l} \mathrm{l}^{-1}$ for $5 \mathrm{~min}$ [51]. In loquat, increase in firmness and reduction of extractable juice is associated with quality loss during storage. Treatment with jasmonates and salicylates reduced quality loss by delaying the lignification $[11,36,51,52]$ and maintaining higher \% of extractable juice, i.e. flesh leatheriness was reduced. Interestingly, higher \% of extractable juice was also observed in peaches treated with MeJA at 1 and $10 \mu \mathrm{mol} \mathrm{l}^{-}$ ${ }^{1}$, stored at $0{ }^{\circ} \mathrm{C}$ plus shelf-life at $20^{\circ} \mathrm{C}[47,48]$ but not in peaches dipped in SA at $50 \mu \mathrm{mol} \mathrm{l}^{-1}$ for 10 min stored at $20^{\circ} \mathrm{C}$ [53], when compared with their untreated counterparts, highlighting that this response is related to reduced chilling injury. Furthermore, the response is dose dependent, since MeJA treatment at 100 and 500 $\mu \mathrm{mol} \mathrm{l}^{-1}$ had no effect on $\%$ of extractable juice [47].

MeJA can prevent mealiness/wooliness development in chilled fruit, through maintaining high PG/PME ratio

Textural quality (edible quality) of some fruit, e.g. peaches, nectarines and loquat may be reduced due to development of flesh mealiness and woolliness, a typical symptom of chilling injury. Flesh mealiness and woolliness are attributed to impaired solubilisation of pectic substances and the accumulation of high amounts of pectin with a low degree of esterification without subsequent depolymerisation, leading to more free water being bound into gel [54]. Occurrence of this symptom is primarily attributed to an imbalance between pectin methyl esterase (PME) and polygalacturonase (PG) activities [55]. The key factor in preventing the development of flesh mealiness and woolliness during cold storage in MeJA treated fruit [11, 36, 47, 48] was the maintenance of high PG/PME ratio, often related to an increase in PG activity.

The positive effects of jasmonates and salicylates on fruit firmness were associated with delayed ripening and senescence [12, 13, 23, 25, 27, 33] and reduced oxidative stress [25, 51, 56], where chilling injury was reduced and fruit texture was better maintained, as indicated by reduced solute leakage (less membrane damage), e.g. in peaches treated with MeJA at $1 \mu \mathrm{mol} \mathrm{l} \mathrm{l}^{-1}$ for $24 \mathrm{~h}$ stored at $0{ }^{\circ} \mathrm{C}$ [56], in pomegranates treated with MeJA and MeSA at 10 and $100 \mu \mathrm{mol} \mathrm{l}^{-1}$ for $16 \mathrm{~h}$ stored at $2{ }^{\circ} \mathrm{C}$ plus shelf-life at $20{ }^{\circ} \mathrm{C}$ [12], Qingnai plums

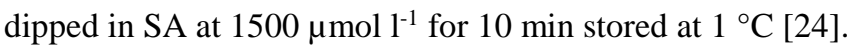

\section{Decay}

Postharvest treatments of fresh produce with jasmonates or salicylates have been found efficient in reducing decay in numerous products $[18,22,24,28,37,49,50,52,57-63]$ (Table 1). Significant reduction in decay was 


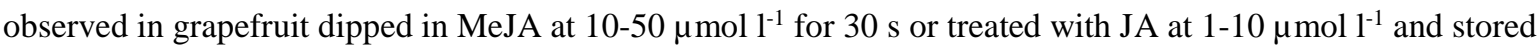
at $2{ }^{\circ} \mathrm{C}$ [19], whereas limited or no benefits, as indicated by only a slight reduction in lesion diameter, were observed in mandarins treated with MeJA at 10-200 $\mu \mathrm{mol} \mathrm{l}^{-1}$ [64] and oranges treated with SA at 750-3000 $\mu \mathrm{mol} \mathrm{l} \mathrm{l}^{-1}$ for 60 or $150 \mathrm{~s}$ [65], stored at $20^{\circ} \mathrm{C}$. This suggests that reduction observed by Droby et al. [19] in treated fruit was associated with reduced chilling injury. Another reason for Moscoso-Ramirez and Palou [65] not seeing any benefits of SA treatment in oranges inoculated with Penicillium digitatum and Penicillium italicum could be the time interval between the treatment and inoculation. These authors inoculated fruit either $24 \mathrm{~h}$ before the dipping in SA or 2-3 h after the treatment, whereas it has been demonstrated that SA can induce resistance against pathogens, but sufficient time is needed [19, 52, 60, 61], so that the fruit can develop this resistance. It has been reported [66] that in pears it may take up to 48 and $72 \mathrm{~h}$ after the treatment with SA to develop disease resistance against Botrytis cinerea and Penicillium expansum, respectively. This would also explain the lack of effect in SA treated apples [67] and pears [66] inoculated with P. expansum $2 \mathrm{~h}$ after the

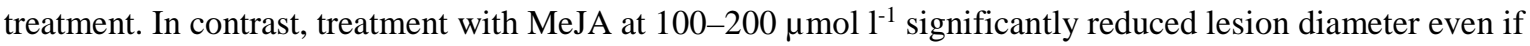
pears were inoculated with $P$. expansum only $2 \mathrm{~h}$ after the treatment [46], which is consistent with the view that defence responses against necrotrophic pathogens are activated and regulated by JA and ethylene rather than by SA signalling pathways [68-70]. Wounding and subsequent treatment with jasmonates would induce the synthesis of JA and ethylene [71, 72]; the involvement of the latter in reducing rots has been proved, e.g. in oranges treated with 1-MCP [73], an ethylene antagonist, where 1-MCP treatment increased chilling injury symptoms and decay development in oranges during storage at $20^{\circ} \mathrm{C}$, suggesting that small amount of ethylene produced by the fruit may be required to maintain their natural resistance against mold rots. Taking into account, however, that postharvest treatments with either jasmonates or salicylates are capable of reducing decay in fresh produce, defence responses to pathogens are clearly regulated by a complex network (cross-talk) of signalling pathways [74].

Storage temperature

Subsequent storage conditions, temperature in particular, are very important for the efficacy of treatment. The lack of effect reported in some studies $[28,75]$ was due to the storage temperature being too high, e.g. SA at 725 $\mu \mathrm{mol} \mathrm{l^{-1 }}$ reduced lesion diameter in strawberries stored at $4{ }^{\circ} \mathrm{C}$, but was not efficient in their counterparts stored at $20^{\circ} \mathrm{C}$ [75]. Similarly, MeJA at $100 \mu \mathrm{mol} \mathrm{l}^{-1}$ reduced the decay in raspberries stored at $10{ }^{\circ} \mathrm{C}$ [28], but was not efficient when produce was stored at $20^{\circ} \mathrm{C}$; berries rapidly deteriorate at such a high temperature. On the other 
hand, at lower temperature, i.e. $0^{\circ} \mathrm{C}$, the quality of raspberries was well preserved and no benefits of volatile treatment could be noticed [28].

In the case of tomatoes, decay was reduced when produce was treated with MeJA at $10 \mu \mathrm{mol} \mathrm{l}^{-1}[76$, 77], $100 \mu \mathrm{mol} \mathrm{l} \mathrm{l}^{-1}[77,78]$, and $200 \mu \mathrm{mol} \mathrm{l}^{-1}[41,79,80]$ or with MeSA at 10 and $100 \mu \mathrm{mol} \mathrm{l} \mathrm{l}^{-1}$ [76, 77]. The positive response was already observed after 3 days of storage at $25^{\circ} \mathrm{C}$ [78] with a significant reduction in disease incidence in tomato fruit inoculated with $B$. cinerea, probably due to fast growth of this fungus at high temperature in control samples. In tomatoes stored at $12-13^{\circ} \mathrm{C}[41,79]$ and $5^{\circ} \mathrm{C}[76,77]$ reduced decay was not noticed until $9^{\text {th }}$ and $21^{\text {st }}$ day of storage, respectively.

Dosage

Higher concentration of these volatiles may counteract their positive effect on disease resistance. Thus, in the case of tomato no benefits were observed if MeJA and MeSA treatments were used at a higher dose of $500 \mu \mathrm{mol}$ $\mathrm{l}^{-1}[77]$. Limited or no benefits were also reported in other commodities, when the treatment dose was too high, e.g. in strawberries, treated with SA at $4000 \mu \mathrm{mol} \mathrm{l}{ }^{-1}$, resulting in slightly damaged fruit [35]. The treatments

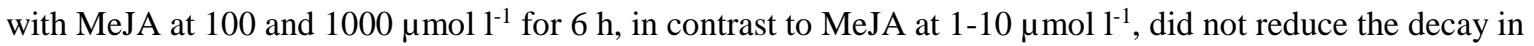
Chinese bayberries [18], as reduced decay was only observed over the first 6 days of storage and then the effect was lost. A similar observation has been reported in pears treated with MeJA at 100 and $200 \mu$ mol $\mathrm{l}^{-1}$ where lesion diameter was significantly reduced, while no effect was observed at lower, i.e. 1 or $10 \mu \mathrm{mol} \mathrm{l} \mathrm{l}^{-1}$ and higher, i.e. $500 \mu \mathrm{mol} \mathrm{l}^{-1}$ concentrations [46]. In grapefruit treated with JA at 1-10 $\mu \mathrm{mol} \mathrm{l}^{-1}$ and inoculated with $P$. digitatum decay was reduced, with no benefits of JA treatment at 0.1 and $1000 \mu \mathrm{mol} \mathrm{l} \mathrm{l}^{-1}$, respectively [19]. On

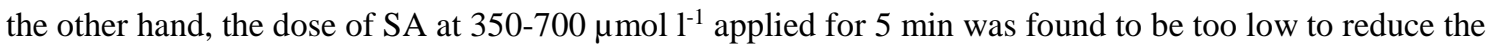
decay in peaches [49]. It is clear from these studies that the concentrations of jasmonates and salicylates have to be properly adjusted for each commodity.

Pathogen sensitivity

Another aspect, that needs to be taken into account, is that jasmonates and salicylates can have a direct effect on fruit pathogens. The in vitro growth of Alternaria alternata was found to be reduced by MeJA at 100-500 $\mu$ mol $\mathrm{l}^{-1}$ [81], inhibition being higher with increasing dose. Similarly, MeJA at $200 \mu \mathrm{mol} \mathrm{l}^{-1}$ inhibited mycelial growth of $P$. expansum, but had only a little effect on Monilinia fructicola [62]. In contrast, JA and MeJA at 1-1000 $\mu \mathrm{mol} \mathrm{l}^{-1}$ had no inhibitory effect on in vitro spore germination and germ tube elongation of $P$. digitatum [19]. In another study, the survival of $B$. cinerea was significantly reduced by SA at 725 and $7250 \mu \mathrm{mol} \mathrm{l}^{-1}$, while these 
treatments had no effect on P. expansum [66]. This finding is supported by Xu and Tian [82], who also observed that SA at $2000 \mu \mathrm{mol} \mathrm{l}^{-1}$ had no effect on mycelia growth and spore germination of $P$. expansum. The spore germination of Rhizopus stolonifer was significantly reduced by SA at 725 and $7250 \mu \mathrm{mol} \mathrm{l}^{-1}$; lower concentrations, however, had no effect [75]. It is evident from the literature that fungal species differ in their sensitivity to these compounds. Furthermore, the results from in vitro studies often do not transfer directly to in vivo situation, highlighting the fact that the effect of the treatment is often not due to antimicrobial action of jasmonates and salicylates but is rather associated with their effects on plant-pathogen interaction, resulting in increased disease resistance [50, 52, 58].

Mechanisms of improving host resistance against pathogens

There are a number of mechanisms involved in improving the resistance of fresh produce to diseases by postharvest treatments with jasmonates and salicylates, e.g. increased accumulation of $\mathrm{H}_{2} \mathrm{O}_{2}[58,63,83,84]$, increased activity of antioxidant enzymes [16, 47, 48, 57, 59, 63, 84], induction of pathogenesis-related (PR) proteins and defence-related enzymes [63, 77, 82] and changes in phenolic biochemistry $[11,47,48,63]$. Disease severity can also be reduced by jasmonates and salicylates indirectly, due to their potential to alleviate chilling injury [49, 77], thus reducing the susceptibility of produce to decay.

No significant difference in $\mathrm{H}_{2} \mathrm{O}_{2}$ content was observed between control and MeJA treated Chinese bayberries [58] and loquat [16] during 8 and 14 days of storage at $1{ }^{\circ} \mathrm{C}$, respectively. Substantial difference between the treatments, however, has been noticed by a number of authors when fresh produce was inoculated with fungal pathogens, i.e. in MeJA treated samples there was a burst in $\mathrm{H}_{2} \mathrm{O}_{2}$ content in loquat inoculated with Colletotrichum acutatum [52], in peaches inoculated with $P$. expansum [63], in tomatoes inoculated with $B$. cinerea [85], Chinese bayberries inoculated with Penicillium citrinum [58], and grapes inoculated with $B$. cinerea $[83,84]$. A similar observation has been reported for mangos treated with SA and inoculated with Colletotrichum gloeosporioides [61]. This initial burst in $\mathrm{H}_{2} \mathrm{O}_{2}$ is considered to play the signalling role responsible for induced disease resistance $[58,63,83,84]$ by enhancing the expression of PR genes and activity of defence related enzymes. Since the increased accumulation of $\mathrm{H}_{2} \mathrm{O}_{2}$ in fresh produce treated with MeJA or SA was observed after the infection, it is clear that these fruit were primed [86, 87], i.e. able to rapidly activate their defence mechanisms when challenged by pathogens. This primed state of the plant is a relatively longlasting phenomenon, as reported by Worrall et al. [88], who observed increased resistance to B. cinerea for up to 8 weeks after the treatment in tomato plants grown from JA treated seeds. 
The accumulated $\mathrm{H}_{2} \mathrm{O}_{2}$ may be involved in inducing PR proteins [77] and defence-related enzymes, e.g. chitinase and $\beta$-1,3-glucanase [50, 58, $62,63,80,82,84]$, when the produce is challenged by the fungal pathogen. These enzymes are capable of hydrolysing polymers of fungal cell walls, and are therefore thought to be implicated in the plant defence mechanisms by reducing fungal growth [89] and thus reducing the decay. It is well known that PAL activity can be induced by both abiotic and biotic stresses [90], e.g. in response to wounding or pathogen attack, where synthesized phenolics could either act directly as defence compounds (phytoalexins) or indirectly, due to being precursors of lignin and suberin, producing a barrier and strengthening cell walls [91], which would prevent the infections through wounds by fungal pathogens and limit pathogen expansion in infected fruit. Substantial increase in PAL activity has indeed been reported in several fruit pretreated with jasmonates or salicylates in response to infection with a pathogen during storage, e.g. in mangos treated with SA at $1000 \mu \mathrm{mol} \mathrm{l} \mathrm{l}^{-1}$ and inoculated with C. gloeosporioides [61], in loquat treated with MeJA at 10 $\mu \mathrm{mol} \mathrm{l}^{-1}$ and inoculated with C. acutatum [52], in peaches treated with MeJA at $1 \mu \mathrm{mol} \mathrm{l^{-1 }}$ and inoculated with P. expansum [63], in Chinese bayberries treated with MeJA at $10 \mu \mathrm{mol} \mathrm{l}^{-1}$ and inoculated with P. citrinum [58]. The increase in PAL, however less pronounced, was also observed in Chinese bayberries [18] and in guava [92] treated with MeJA at $10 \mu \mathrm{mol} \mathrm{l} \mathrm{l}^{-1}$ without inoculation, confirming that role of PAL is more complex than just its involvement in response to pathogens. A strong increase in PAL activity in response to pathogens in treated samples further supports the idea of primed state of the plant [87].

Even though the content of total phenolics was increased in loquat [52] and Chinese bayberries [58]

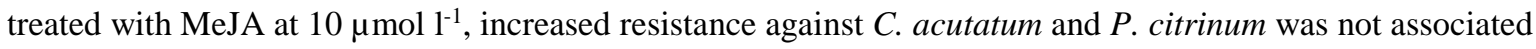
with lignin content, which was actually reduced [52], or not affected until 6 and $8^{\text {th }}$ day of storage [58] in inoculated and non-inoculated MeJA treated samples, respectively. These findings suggest that lignin is probably not the key player in preventing decay in MeJA treated fruit. Furthermore, increased resistance is not associated with total phenolics content per se but rather relates to the presence of specific compounds, e.g. phytoalexins which have been found to be substantially increased in Chinese bayberries treated with MeJA at 10 $\mu \mathrm{mol} \mathrm{l} \mathrm{l}^{-1}[58]$.

Although an increase in reactive oxygen species (ROS), e.g. $\mathrm{O}_{2}{ }^{-}, \mathrm{H}_{2} \mathrm{O}_{2}$ could contribute to the enhancement of disease resistance in plant tissues, to avoid excess oxidative stress these molecules need to be scavenged by the antioxidants (e.g. ascorbic acid, phenolic compounds) and antioxidant enzymes (e.g. superoxide dismutase (SOD), catalase (CAT), ascorbate peroxidase (APX)) [93]. Antioxidant activity has 
indeed been found to be increased in MeJA treated fruit, e.g. in raspberries treated with MeJA at $100 \mu \mathrm{mol}^{-1}$ [59] and peaches treated with MeJA at $1 \mu \mathrm{mol} \mathrm{l}^{-1}[47,48,63]$.

Reduced decay due to reduced chilling injury

Reduced decay in fresh produce treated with jasmonates or salicylates is often associated with reduced chilling injury, as reported for mangos treated with MeJA at 10 and $100 \mu \mathrm{mol} \mathrm{l}{ }^{-1}$ stored at $5{ }^{\circ} \mathrm{C}$ [40], tomatoes treated with MeJA or MeSA at $10 \mu \mathrm{mol} \mathrm{l}^{-1}$ for $16 \mathrm{~h}$ stored at $5{ }^{\circ} \mathrm{C}[76,77]$, peaches dipped in SA at $1000 \mu \mathrm{mol} \mathrm{l}^{-1}$ for 5 min stored at $0^{\circ} \mathrm{C}$ [49] or Qingnai plums dipped in SA at $1500 \mu \mathrm{mol} \mathrm{l} \mathrm{l}^{-1}$ for $10 \mathrm{~min}$ stored at $1^{\circ} \mathrm{C}$ [24]. One key issue with chilling injured fruit is the textural quality loss due to alterations in membrane structure [15], making the produce more susceptible to rots and decay.

It has been reported in the majority of studies that reduced membrane damage often observed in fresh produce, e.g. in kiwi [33], loquat [16], mango [43], peaches [94] treated with jasmonates and salicylates is due to reduced activity of lipoxygenase (LOX), an enzyme responsible for generation of superoxide free radicals, which if not scavenged by an antioxidant system could lead to peroxidation of lipids, i.e. affecting unsaturated/saturated fatty acid composition [16]. This would eventually lead to accumulation of malondialdehyde (MDA) and increased solute leakage. The content of MDA was indeed found to be reduced in Qingnai plums treated with MeJA [24], peaches treated with MeJA [56], and custard apples treated with SA [25]. Wang et al. [49], however, observed that the dose used has to be properly adjusted, since these authors only observed reduced lipid peroxidation in peaches dipped in SA at $1000 \mu \mathrm{mol} \mathrm{l}^{-1}$ for 5 min, i.e. in those fruit where chilling injury and decay were reduced, while lower doses of 350 and $700 \mu \mathrm{mol} \mathrm{l} \mathrm{l}^{-1}$ were not efficient.

In some cases, however, the treatment with jasmonates prior to storage may lead to increased LOX activity, e.g. when produce is challenged by a pathogen, where increased production of ROS is used as a signal to prevent the produce from infection and limit the spread of disease, as has been observed in tomatoes treated with MeJA at $100 \mu \mathrm{mol} \mathrm{l} \mathrm{l}^{-1}$ for $30 \mathrm{~s}$ and then inoculated with B. cinerea [78].

Mechanisms of chilling injury have been described in more detail elsewhere [15], however, it is worth noting that membrane stability has been improved in numerous produce treated with jasmonates and salicylates prior to cold storage, e.g. in loquat treated with MeJA at $10 \mu \mathrm{mol} \mathrm{l^{-1 }}$ for $24 \mathrm{~h}$, stored at $1^{\circ} \mathrm{C}$ [11], mangos treated with MeJA at $100 \mu \mathrm{mol} \mathrm{l}^{-1}$ for $24 \mathrm{~h}$, stored at $7^{\circ} \mathrm{C}$ plus shelf-life at $20^{\circ} \mathrm{C}$ [26], pomegranates treated with MeJA and MeSA at 10 and $100 \mu \mathrm{mol} \mathrm{l} \mathrm{l}^{-1}$ for $16 \mathrm{~h}$, stored at $2{ }^{\circ} \mathrm{C}$ plus shelf-life at $20^{\circ} \mathrm{C}$ [12], Qingnai plums treated with SA at $1500 \mu \mathrm{mol} \mathrm{l} \mathrm{l}^{-1}$ for $10 \mathrm{~min}$, stored at $1{ }^{\circ} \mathrm{C}$ plus shelf-life at $20{ }^{\circ} \mathrm{C}$ [24], and tomatoes treated with MeSA at $50 \mu \mathrm{mol} \mathrm{l} \mathrm{l}^{-1}$ for $12 \mathrm{~h}$, stored at $2^{\circ} \mathrm{C}$ [14]. The mechanisms involved are related to changes in the 
content of polyamines [14, 24, 60, 34, 95] and proline [10, 95, 96], cell wall modification [11], the energy status $[56,60]$ and changes in the membrane fatty acid composition [16, 97].

Polyamines (PAs) are well known for their ability to stabilise membranes and cell walls [98, 99], and have been reported to be involved in increasing tolerance of fruit to cold temperatures, thus alleviating chilling injury, e.g. in peaches dipped in SA at $1000 \mu \mathrm{mol} \mathrm{l}^{-1}$ for $5 \mathrm{~min}$, stored at $0{ }^{\circ} \mathrm{C}$ [94], in Qingnai plums treated with SA at $1500 \mu \mathrm{mol} \mathrm{l} \mathrm{l}^{-1}$ for $10 \mathrm{~min}$, stored at $1{ }^{\circ} \mathrm{C}$ plus shelf-life at $20^{\circ} \mathrm{C}$ [24], and tomatoes treated with MeJA at $50 \mu \mathrm{mol} \mathrm{l}^{-1}$ for $12 \mathrm{~h}$ [95] or with MeSA at $50 \mu \mathrm{mol} \mathrm{l}^{-1}$ for $12 \mathrm{~h} \mathrm{[14]} \mathrm{stored} \mathrm{at} 2{ }^{\circ} \mathrm{C}$.

Polyamines have recently been linked with increased resistance to rots in MeJA treated loquat fruit [60] however, it seems more likely $[100,101]$ that delayed infection in MeJA treated loquat fruit inoculated with $C$. acutatum was associated with improved membrane stability and increased activity of chitinase and $\beta-1,3-$ glucanase [50]. Cao et al. [60] also observed increased ATP content in MeJA treated loquat fruit which would help in maintaining membrane stability, whereas at low ATP level and energy status, membrane lipids could be used in respiration [102, 103], weakening cell integrity and accelerating senescence, thus facilitating pathogen infection. This is in agreement with Jin et al. [56] who reported higher ATP content in MeJA treated peaches accompanied with reduced membrane damage, indicated by reduced ion leakage and malondialdehyde (MDA) content, the product of lipid peroxidation which is a reflection of stress-induced damage at the cellular level caused by ROS.

Finally, the positive role of increased PA content in fruit treated with jasmonates and salicylates, could be due to the fact that they act in the opposite way to ethylene with respect to fruit ripening and senescence [98], thus in fruit with high levels of PAs these processes may be delayed.

A number of authors have found that improved chilling tolerance and thus reduced susceptibility to rots and decay during cold storage in MeJA treated fruit, e.g. in banana treated with MeJA at $100 \mu \mathrm{mol} \mathrm{l}^{-1}$ for 30 min, stored at $7{ }^{\circ} \mathrm{C}$ [96], in loquat treated with MeJA at $10 \mu$ mol l $^{-1}$ for $24 \mathrm{~h}$, stored at $1{ }^{\circ} \mathrm{C}$ [10], and tomatoes treated with MeJA at $50 \mu \mathrm{mol} \mathrm{l}^{-1}$ for $12 \mathrm{~h}$, stored at $2{ }^{\circ} \mathrm{C}$ [95] was also associated with increased content of proline, which is involved in osmotic regulation, preventing cells from dehydration and improving turgor maintenance during storage, supporting the role of PAs.

Membrane integrity and fluidity was also found to be improved in loquat fruit treated with MeJA at 10 $\mu$ mol $\mathrm{l}^{-1}$ for $24 \mathrm{~h}$, stored at $1^{\circ} \mathrm{C}[16]$ due to an increased ratio of unsaturated/saturated fatty acids which has been reported to be associated with reduced susceptibility to chilling injury [97]. 


\section{Visual quality}

Visual quality maintenance of fruit during storage, transit and shelf-life display is an important aspect for the food supply chain, since fresh produce with good appearance is preferred by customers and retailers.

Marketability of the produce may be reduced by the presence of decay, visible injuries, i.e. pitting and sunken lesions on the peel [26, 27, 96], discoloration associated with ripening, changes in pigments content [29, 40, 104], and/or due to external and internal tissue browning [12, 13, 44].

A number of authors observed improved appearance of the produce treated with jasmonates and salicylates prior to storage, e.g. in guava fruit treated with MeJA at 10 and $100 \mu \mathrm{mol} \mathrm{l} \mathrm{l}^{-1}$, stored at $5{ }^{\circ} \mathrm{C}$ plus shelf-life at $20^{\circ} \mathrm{C}$ [92], in mangos treated with MeSA at $100 \mu \mathrm{mol} \mathrm{l}^{-1}$, stored at $5^{\circ} \mathrm{C}$ [44] or with MeJA at 10 and $100 \mu \mathrm{mol} \mathrm{l}^{-1}$ during storage at 5 and $10^{\circ} \mathrm{C}$ plus shelf-life at $20^{\circ} \mathrm{C}$; the benefits were more pronounced in mangos stored at $5{ }^{\circ} \mathrm{C}[40]$. The appearance was also improved in papaya treated with MeJA at 10 and $100 \mu \mathrm{mol}$ $\mathrm{l}^{-1}$, stored at $10^{\circ} \mathrm{C}$ plus shelf-life at $20^{\circ} \mathrm{C}$ [27], in peaches treated with MeJA at $100 \mu \mathrm{mol} \mathrm{l}^{-1}$ for $12 \mathrm{~h}$, subsequently stored at $5{ }^{\circ} \mathrm{C}$ [8], and in pomegranates dipped in ASA at $100-1000 \mu \mathrm{mol} \mathrm{l} \mathrm{l}^{-1}$ for $10 \mathrm{~min}$ [13] or

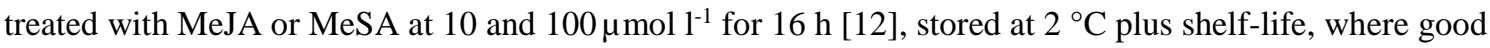
appearance was maintained in contrast to poor quality in untreated samples.

Overall visual quality was also improved in strawberries treated with MeJA at $100 \mu \mathrm{mol}^{-1}$, stored at $7.5^{\circ} \mathrm{C}$ [22] or treated with SA at $2000 \mu \mathrm{mol} \mathrm{l}^{-1}$ [35], in banana dipped in MeJA at $100 \mu \mathrm{mol} \mathrm{l} \mathrm{l}^{-1}$ for $30 \mathrm{~min}$, subsequently stored at $7{ }^{\circ} \mathrm{C}$ [96], in grapefruit dipped in JA at 10 and $50 \mu \mathrm{mol} \mathrm{l}^{-1}$ for $30 \mathrm{~s}$, stored at $2{ }^{\circ} \mathrm{C}$ plus shelf-life at $20^{\circ} \mathrm{C}$ [19], in tomatoes treated with MeSA or MeJA at $10 \mu \mathrm{mol} \mathrm{l} \mathrm{l}^{-1}$ for $16 \mathrm{~h}$, stored at $5^{\circ} \mathrm{C}$ plus shelf-life at $20^{\circ} \mathrm{C}[76]$ or treated with MeSA at $100 \mu \mathrm{mol} \mathrm{l}^{-1}$ [105], and bell peppers treated with MeJA and MeSA at $100 \mu \mathrm{mol} \mathrm{l} \mathrm{l}^{-1}$, stored at $0{ }^{\circ} \mathrm{C}[106]$. The majority of these positive responses were associated with the ability of jasmonates and salicylates to prevent chilling injury and/or decay in the produce, which is a welldocumented phenomenon of these compounds [49, 56, 95, 97, 107].

Effect of jasmonates and salicylates on visual quality of fresh produce may also be associated with their impact on ripening [27, 29, 108]. Fan et al. [108] observed that in Golden Delicious apples treated with MeJA vapour at $10000 \mu \mathrm{mol} \mathrm{l}^{-1}$ and in Fuji apples dipped in JA at 100, 1000 and $1000 \mu \mathrm{mol} \mathrm{l}^{-1}$ for 2 min, held at $22{ }^{\circ} \mathrm{C}$, the degreening process (the change from green to yellow) was promoted, while no effect was observed at

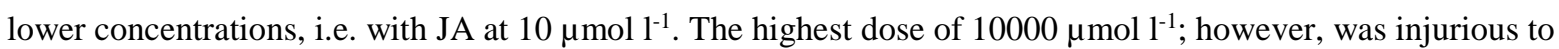
the fruit, manifested as round brown spots near the calyx end of the fruit. These authors also found that the most significant effects were observed in apples $157 \mathrm{~d}$ after full bloom, where the ethylene biosynthesis has just been 
initiated, while as fruit development progressed, apples became less sensitive to exogenous MeJA. This suggests an interaction of JA with ethylene regulated processes. Acceleration or red colour acquisition by MeJA treatment has been confirmed in Fuji apples dipped in MeJA at 500 and $1000 \mu \mathrm{mol}^{-1}$ for 2 min $[104,109]$, making it clear that treatment with MeJA promotes ripening.

Colouration

It has been demonstrated in tomatoes [29] that the effect of MeSA treatment on red colour development depends on both the concentration being used and the developmental stage of the fruit. Treatment with MeSA at $10 \mu \mathrm{mol} \mathrm{l}^{-1}$ for $16 \mathrm{~h}$ enhanced red colour acquisition in tomatoes at breaker stage but had no effect on their counterparts at green mature stage, while at turning stage, colour acquisition was delayed. Interestingly, MeSA at $100 \mu \mathrm{mol} \mathrm{l^{-1 }}$ accelerated red colour acquisition at green mature stage, but delayed red colour development at breaker and turning stage. At higher dose of $500 \mu \mathrm{mol} \mathrm{l}^{-1}$, red colour acquisition was inhibited at all developmental stages, i.e. tomatoes were never fully red [29, 77]. On the other hand, treatment of pink tomatoes with MeJA vapour at $100 \mu \mathrm{mol} \mathrm{l}^{-1}$ had no significant effect on fruit redness during subsequent storage [105]. Similarly, no response to MeJA, in terms of colour change, was observed in tomatoes at breaker stage dipped in MeJA at $1000 \mu \mathrm{mol} \mathrm{l}^{-1}$ for 15 min [45]. These findings suggest that jasmonates and salicylates interact with ripening process in a different way; high concentration of SA delays fruit ripening by reducing ethylene production, while low concentration would promote it. In case of JA, which in general accelerates fruit ripening by increasing ethylene production, the effect seems to be commodity and cultivar specific, e.g. treatment with MeJA at $5000 \mu \mathrm{mol} \mathrm{l}^{-1}$ for 5 min decreased internal ethylene concentrations during storage in Delicious apples compared with the untreated control, but had no effect in Golden Delicious apples [108]. On the other hand, lower dose of MeJA, i.e. $10 \mu \mathrm{mol} \mathrm{l} \mathrm{l}^{-1}$ for $20 \mathrm{~h}$ accelerated colour acquisition in mango fruit stored at 5 and $20^{\circ} \mathrm{C}$ [40], while higher concentration of $100 \mu \mathrm{mol} \mathrm{l}^{-1}$ had either no effect or slightly delayed changes in colour characteristics of mangos stored at 5,7 and $20^{\circ} \mathrm{C}[26,40]$, suggesting that low concentration may promote ripening. These authors [27] also observed delay in fruit yellowing in papaya treated with MeJA at 10 and 100 $\mu \mathrm{mol} \mathrm{l} \mathrm{l}^{-1}$ for $20 \mathrm{~h}$, stored at $10^{\circ} \mathrm{C}$; delay was longer at the higher dose of $100 \mu \mathrm{mol} \mathrm{l} \mathrm{l}^{-1}$.

Better colour maintenance was observed in raspberries treated with MeJA at $100 \mu \mathrm{mol} \mathrm{l}^{-1}$ and stored at $10{ }^{\circ} \mathrm{C}$, while at $0{ }^{\circ} \mathrm{C}$ the difference could not be detected [28]. Thus, it is not surprising that Shafiee et al. [38] could not see the difference in colour between untreated strawberries and their counterparts dipped in SA at $2000 \mu \mathrm{mol} \mathrm{l} \mathrm{l}^{-1}$ for $15 \mathrm{~min}$, when stored at $2{ }^{\circ} \mathrm{C}$. In contrast, colour maintenance was improved in peaches dipped in SA at 500-2000 $\mu \mathrm{mol} \mathrm{l}^{-1}$ for $5 \mathrm{~min}$ stored at $0{ }^{\circ} \mathrm{C}$ [37], mainly due to reduced chilling injury and decay. 
In a number of studies colour alteration was related to changes in pigment content, e.g. in apples treatment with MeJA increased $\beta$-carotene content [104, 110], while in tomatoes treated with MeJA at $200 \mu$ mol $\mathrm{l}^{-1}[41]$ and $500 \mu \mathrm{mol} \mathrm{l^{-1 }}$ [111] red colour development was associated with increased lycopene content, whereas $\beta$-carotene content was not affected [41]. Increase in redness value could also be due to an increase in anthocyanin content observed in numerous studies, e.g. in apples treated with MeJA at 500 and $1000 \mu \mu_{0} \mathrm{l}^{-1}$ for $2 \min$ [104, 109], in pomegranates treated with ASA at 100, 500 and $1000 \mu \mathrm{mol} \mathrm{l}^{-1}$ for 10 min [13] or with MeJA and MeSA at 10 and $100 \mu \mathrm{mol} \mathrm{l} \mathrm{l}^{-1}$ for $16 \mathrm{~h} \mathrm{[12],} \mathrm{stored} \mathrm{at} 2{ }^{\circ} \mathrm{C}$. Anthocyanin content was also increased in MeJA treated raspberries [59], strawberries [22, 112], blackberries [113] and Chinese bayberries [18]. Interestingly, in cherries dipped in SA and ASA at $1000 \mu \mathrm{mol} \mathrm{l}^{-1}$ for $10 \mathrm{~min}$, the increase in anthocyanin content was slower when compared with control, which was associated with delayed ripening [42].

External and internal browning

Finally, visual quality of the produce can be reduced by tissue browning, which is often associated with texture loss, since browning appears when texture and membrane integrity are reduced. A number of studies found positive effects of jasmonates and salicylates in reducing internal and external browning of fresh produce, e.g. in loquat fruit dipped in ASA at $1000 \mu \mathrm{mol} \mathrm{l} \mathrm{l}^{-1}$ for $5 \mathrm{~min}$, subsequently stored at $0^{\circ} \mathrm{C}$, both external (skin) and internal (flesh) browning was significantly reduced [51]. In more recent studies, it has been reported that internal browning in loquat can also be reduced by treating fruit with MeJA at $10 \mu \mathrm{mol} \mathrm{l} \mathrm{l}^{-1}$ for $24 \mathrm{~h}[16$, 50]. The response during storage, however, may vary due to cultivar being used, since Cao et al. [97] reported that not all loquat varieties are susceptible to chilling injury. These authors compared the behaviour of two loquat fruit cultivars, i.e. Fuyang and Qingzhong during storage at $1{ }^{\circ} \mathrm{C}$ and found that internal browning increased only in the Fuyang cultivar. Reduced internal browning was also observed in peaches treated with MeJA at $1 \mu$ mol l-1 for $24 \mathrm{~h}[47,48]$ and MeJA at $16 \mu \mathrm{mol} \mathrm{l}^{-1}$ for $6 \mathrm{~h}[36]$, when stored at $0-1{ }^{\circ} \mathrm{C}$.

Other authors found reduced skin browning in pomegranates treated with ASA at 100, 500 and 1000 $\mu \mathrm{mol} \mathrm{l}^{-1}$ for $10 \mathrm{~min}$ [13] or treated with MeJA or MeSA at 10 and $100 \mu \mathrm{mol} \mathrm{l}^{-1}$ for $16 \mathrm{~h}$ [12] stored at $2{ }^{\circ} \mathrm{C}$, and in banana treated with $\mathrm{MeJA}$ at $100 \mu \mathrm{mol} \mathrm{l} \mathrm{l}^{-1}$ for $30 \mathrm{~min}$, stored at $7^{\circ} \mathrm{C}$ [96], these changes were associated with reduced chilling injury.

\section{Organoleptic quality}

The taste of the product can be affected by a number of factors, e.g. sugar content and composition, organic acids and texture-related mouth feel $[114,115]$, whereas changes in the aroma are related to changes in volatile 
compound composition [116, 117]. Both taste and aroma together, define the product's flavour, i.e. the way it is perceived by the consumers.

Taste

Many studies have investigated the effect of jasmonates and salicylates treatments on soluble solids, sugar content and acidity in fresh produce. Higher content of soluble solids, sugars and organic acids may be associated with lower metabolism, i.e. reduced respiration and delayed senescence. Higher soluble solids and acidity were indeed observed in loquat treated with MeJA at $10 \mu \mathrm{mol} \mathrm{l} \mathrm{l}^{-1}$ for $24 \mathrm{~h}$ stored at $20^{\circ} \mathrm{C}$ [50], strawberries treated with MeJA at $100 \mu \mathrm{mol} \mathrm{l}^{-1}$ and stored at $7.5^{\circ} \mathrm{C}$ [22], where produce quality was better maintained compared with their untreated counterparts. On the other hand, soluble solids were not affected in Chinese bayberries treated with $\mathrm{MeJA}$ at 1-1000 $\mu \mathrm{mol} \mathrm{l}^{-1}$ stored at $0{ }^{\circ} \mathrm{C}[18]$ and in strawberries dipped in SA at $2000 \mu \mathrm{mol} \mathrm{l} \mathrm{l}^{-1}$ for $15 \mathrm{~min}$ and stored at $2{ }^{\circ} \mathrm{C}$ [38]; at lower temperatures, i.e. $0-2{ }^{\circ} \mathrm{C}$, the quality of berries was well preserved and no effect of the treatment was noticed.

Higher fructose and glucose content was observed in raspberries treated with MeJA at $100 \mu \mathrm{mol} \mathrm{l}^{-1}$ and stored at $10^{\circ} \mathrm{C}[28]$, where decay was significantly reduced. Higher content of soluble solids, sugars and organic acids was also reported in a number of studies, where chilling injury was reduced, e.g. in loquat treated with MeJA at $10 \mu \mathrm{mol} \mathrm{l} \mathrm{l}^{-1}$ for $24 \mathrm{~h}$ [17] or at $16 \mu \mathrm{mol} \mathrm{l}^{-1}$ for $6 \mathrm{~h}$ [36], subsequently stored at $1^{\circ} \mathrm{C}$, in mangos treated with MeJA at $10 \mu \mathrm{mol} \mathrm{l} \mathrm{l}^{-1}$ for $20 \mathrm{~h}$, stored at $5^{\circ} \mathrm{C}$ [40], $100 \mu \mathrm{mol} \mathrm{l} \mathrm{l}^{-1}$ for $24 \mathrm{~h}$, subsequently stored at $7^{\circ} \mathrm{C}$ [26] or dipped in SA at $2000 \mu \mathrm{mol} \mathrm{l} \mathrm{l}^{-1}$ for $10 \mathrm{~min}$, stored at $5{ }^{\circ} \mathrm{C}$ [43], in peaches treated with MeJA at 1 and 10

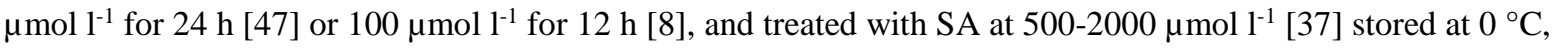
but were not affected by MeJA at 100 and $500 \mu \mathrm{mol} \mathrm{l}^{-1}$ for $24 \mathrm{~h}$ [47], suggesting that higher doses may have no benefits. In white guava fruit, treatment with MeJA at 10 and $100 \mu \mathrm{mol} \mathrm{l} \mathrm{l}^{-1}$ for $8 \mathrm{~h}$ increased fructose and sucrose level, while glucose was not affected [92]. In red guava fruit stored at $5^{\circ} \mathrm{C}$, the content of all sugars was increased, suggesting accelerated ripening in response to MeJA treatment.

The changes in the level of soluble solids and sugar content could also be associated with fruit maturity. They increase during fruit ripening, and start to decline when fruit become over-ripe. The content of soluble solids was reduced in cherries dipped in SA and ASA at $1000 \mu \mathrm{mol} \mathrm{l} \mathrm{l}^{-1}$ for $10 \mathrm{~min}$ and stored at $2{ }^{\circ} \mathrm{C}$ [42], in peppers dipped in SA at 1000-4000 $\mu \mathrm{mol} \mathrm{l} \mathrm{l}^{-1}$ for $15 \mathrm{~min}$ and stored at 10 or $25^{\circ} \mathrm{C}$ [39], and in custard apples dipped in SA at 400, 800 and $1200 \mu \mathrm{mol} \mathrm{l}^{-1}$ for 15 min stored at $15^{\circ} \mathrm{C}$ [25]. The content of reducing sugars was also reduced in banana dipped in SA at 500 and $1000 \mu \mathrm{mol} \mathrm{l} \mathrm{l}^{-1}$ for $6 \mathrm{~h} \mathrm{[23];} \mathrm{these} \mathrm{changes} \mathrm{were} \mathrm{due}$ to delayed ripening. 
Interestingly, soluble solids and sugars were not affected in pomegranates treated with SA at 700, 1400 and $2000 \mu \mathrm{mol} \mathrm{l}^{-1}$ [107] or with ASA at 100, 500 and $1000 \mu \mathrm{mol} \mathrm{l}^{-1}$ [13] stored at $2{ }^{\circ} \mathrm{C}$. The content of soluble solids, however, did not change significantly over the whole storage period of 3 months.

\section{Aroma}

Aroma production increases with ripening and is often associated with ethylene signalling $[29,108]$. There is clear evidence that jasmonates and salicylates may affect fruit ripening as demonstrated in apples [104, 108], banana [23], cherries [42], kiwi [33], mangos [40], papaya [27] and tomatoes [29]. The information on the effects of these chemicals on aroma volatiles, however, is scarce and limited to strawberries [22, 112, 118] and apples [119, 120]. Interestingly, volatile emission was found to be increased in MeJA treated strawberries, either due to MeJA promoted ripening [112, 118] or reduced decay [22], which were both associated with higher sugar content in MeJA treated samples. In apples, which are climacteric fruit, treatment with MeJA vapour at 8000 $\mu \mathrm{mol} \mathrm{l}^{-1}$ for $4 \mathrm{~h}$ [119] or dipping in MeJA at $5000 \mu \mathrm{mol} \mathrm{l}^{-1}$ for 5 min [120] reduced volatile biosynthesis, due to a decline in ethylene production.

\section{Nutritional quality}

Reactive oxygen species (ROS) are produced during cellular metabolism; however, in response to environmental stresses, e.g. low temperature, their production may increase. ROS include such compounds as superoxide radicals $\left(\mathrm{O}_{2}^{-}\right)$, singlet oxygen $\left({ }^{1} \mathrm{O}_{2}\right)$ and highly reactive hydroxyl radicals $\left(\mathrm{OH}^{-}\right)$. SOD catalyses the dismutation of superoxide $\left(\mathrm{O}_{2}^{-}\right)$to $\mathrm{H}_{2} \mathrm{O}_{2}$ which is then transformed to $\mathrm{H}_{2} \mathrm{O}$ and $\mathrm{O}_{2}$ by simultaneous action of ascorbate peroxidase (APX) and catalase (CAT). To mitigate ROS, the biosynthesis of antioxidants e.g. ascorbic acid (AsA), which is involved in the reduction of ROS through the ascorbate-glutathione cycle [93, 121], may be induced. Other antioxidants, i.e. phenolic compounds may also play an important role as ROS scavengers [122]. On the other hand, ROS have also been shown to play a role of signalling molecules. Thus, as a result of cross-talk, they may induce different defence responses, e.g. in response to pathogens or to multiple stresses [93, 123].

Antioxidant activity

It has been reported in numerous studies that treatment with jasmonates and salicylates prior to storage increased antioxidant activity of fresh produce during storage, in this way improving its ability to withstand stress and extend its shelf-life. Higher antioxidant capacity has been reported in Chinese bayberries treated with MeJA at $10 \mu \mathrm{mol} \mathrm{l}^{-1}$ for $6 \mathrm{~h}$, stored at $0^{\circ} \mathrm{C}$ [18], in blueberries treated with MeJA at $50 \mu \mathrm{mol} \mathrm{l}{ }^{-1}$ for $12 \mathrm{~h}$, stored 
at $1{ }^{\circ} \mathrm{C}$ [124], in blackberries treated with MeJA at $100 \mu \mathrm{mol} \mathrm{l}^{-1}$, stored at $10{ }^{\circ} \mathrm{C}$ [57], in strawberries treated with MeJA at $100 \mu \mathrm{mol} \mathrm{l} \mathrm{l}^{-1}$, stored at $7.5^{\circ} \mathrm{C}$ [22] and $10^{\circ} \mathrm{C}$ [57], in raspberries treated with MeJA at $100 \mu \mathrm{mol} \mathrm{l^{- }}$ ${ }^{1}$, stored at $10^{\circ} \mathrm{C}[59]$ and loquat fruit treated with MeJA at $10 \mu \mathrm{mol} \mathrm{l}{ }^{-1}$, stored at $1^{\circ} \mathrm{C}$ [17]. Similarly, higher antioxidant activity was observed in peaches treated with SA at 500-2000 $\mu \mathrm{mol} \mathrm{l}{ }^{-1}$, stored at $0{ }^{\circ} \mathrm{C}$ [37], pomegranates treated with ASA at 100, 500 and $1000 \mu \mathrm{mol} \mathrm{l}{ }^{-1}$, stored at $2{ }^{\circ} \mathrm{C}$ [13], and cornelian cherry fruit treated with SA at $1000 \mu \mathrm{mol} \mathrm{l}^{-1}$, stored at $4{ }^{\circ} \mathrm{C}$ [125]. Antioxidant activity increased in untreated cherry fruit during the first 10 days of storage at $2{ }^{\circ} \mathrm{C}$ and then decreased, while in fruits treated with SA at $1000 \mu \mathrm{mol} \mathrm{l}^{-1}$ for 10 min prior to storage, antioxidant activity increased continuously during storage [42].

Vitamin C content

Good maintenance of quality is often associated with maintenance of AsA. It has been demonstrated in numerous studies that AsA content can be improved in fresh produce treated with jasmonates and salicylates. AsA content was increased in cornelian cherry fruit dipped in SA at 1000 and $2000 \mu \mathrm{mol} \mathrm{l}^{-1}$ for 5 min, stored at $4{ }^{\circ} \mathrm{C}$ [125] and pineapple treated with SA at $5000 \mu \mathrm{mol} \mathrm{l} \mathrm{l}^{-1}$ for $15 \mathrm{~min}$ stored at $10{ }^{\circ} \mathrm{C}$ [126]. Similarly, in oranges dipped in SA at $2000 \mu \mathrm{mol} \mathrm{l} \mathrm{l}^{-1}$ for $30 \mathrm{~min}$, stored at 6 and $20{ }^{\circ} \mathrm{C}$ the content of AsA was increased, while the content of dehydroascorbic acid (DHA) was lower [20], thus, the AsA/DHA ratio was significantly increased in SA treated fruit; the content of DHA is often used as an indication of oxidative stress [93].

Higher AsA and lower DHA were reported in loquat treated with MeJA at $10 \mu \mathrm{mol} \mathrm{l}^{-1}$ for $24 \mathrm{~h}$, stored at $1{ }^{\circ} \mathrm{C}$ [9]. Interestingly, in raspberries treated with MeJA at $100 \mu \mathrm{mol} \mathrm{l^{-1 }}$ and stored at $10{ }^{\circ} \mathrm{C}$ the content of both AsA and DHA was increased [59], suggesting de novo biosynthesis of AsA during storage; its loss was also reduced compared with untreated samples, due to increased activity of monodehydroascorbate reductase (MDHAR) and dehydroascorbate reductase (DHAR).

On the other hand, AsA loss during storage was only slightly reduced in blueberries treated with MeJA

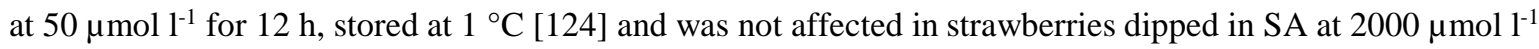
for $15 \mathrm{~min}$, stored at $2{ }^{\circ} \mathrm{C}$ [38]. These results are not surprising, since at lower temperatures, i.e. $1-2{ }^{\circ} \mathrm{C}$, the quality loss in berries is relatively slow.

Higher vitamin C (AsA + DHA) content was observed in peaches treated with MeJA at $1 \mu$ mol l-1 [47, 48] and $10 \mu \mathrm{mol} \mathrm{l}^{-1}$ [47], stored at $0^{\circ} \mathrm{C}$, while no effect was observed at higher doses of 100 and $500 \mu \mathrm{mol} \mathrm{l}^{-1}$ [47]. The loss of AsA was also reduced in peaches treated with SA at $1000 \mu \mathrm{mol} \mathrm{l} \mathrm{l}^{-1}$ for $5 \mathrm{~min}$, stored at $0{ }^{\circ} \mathrm{C}$ [49]; however, due to an increase in DHA content in untreated samples, the content of vitamin C was not significantly affected. 
Higher AsA content was reported in tomatoes treated with MeJA at $200 \mu \mathrm{mol} \mathrm{l} \mathrm{l}^{-1}$, stored at $13{ }^{\circ} \mathrm{C}$ [41] and at $10000 \mu \mathrm{mol} \mathrm{l} \mathrm{l}^{-1}$ for $10 \mathrm{~min}$, stored at $25^{\circ} \mathrm{C}$ [85], where decay was reduced due to increased activity of ascorbate-glutathione cycle in MeJA treated samples.

On the other hand, vitamin C content was not affected in white guava fruit treated with MeJA at 10 and $100 \mu \mathrm{mol} \mathrm{l} \mathrm{l}^{-1}$ for $8 \mathrm{~h}$ stored at $5^{\circ} \mathrm{C}$, whereas an increase was reported in their red counterparts after 10 and $15 \mathrm{~d}$ of storage [92]. These authors concluded that response to MeJA treatment may depend upon the cultivar. Similarly, in more recent studies [13, 107], higher AsA content was observed in pomegranates cv. Mollar de Elche treated with ASA at 100, 500 and $1000 \mu \mathrm{mol} \mathrm{l}^{-1}$ for $10 \mathrm{~min}$, stored at $2^{\circ} \mathrm{C}$ [13], while no effect was observed in cv. Malas Saveh treated with SA at 700 and $1400 \mu \mathrm{mol} \mathrm{l} \mathrm{l}^{-1}$ for $10 \mathrm{~min}$, stored at $2{ }^{\circ} \mathrm{C}$ [107].

Total phenolic content

Total phenolics and flavonoids content was found to be increased in Chinese bayberries treated with MeJA at 10 $\mu \mathrm{mol} \mathrm{l}^{-1}$ for $6 \mathrm{~h}$, stored at $0^{\circ} \mathrm{C}[18]$, strawberries treated with MeJA at $100 \mu \mathrm{mol} \mathrm{l} \mathrm{l}^{-1}$, stored at $7.5^{\circ} \mathrm{C}$ [22], raspberries treated with MeJA at $100 \mu \mathrm{mol} \mathrm{l}^{-1}$ for $16 \mathrm{~h}$, stored at $10{ }^{\circ} \mathrm{C}$ [59], but was not affected in raspberries treated with MeJA at 10 and $100 \mu \mathrm{mol} \mathrm{l}^{-1}$ for $24 \mathrm{~h}$, stored at $4{ }^{\circ} \mathrm{C}$ [127], probably due to differences in storage temperatures between those studies and relatively short length, i.e. 5 days of the trial conducted by Flores and Ruiz del Castillo [127].

Higher total phenolic content was also observed in cornelian cherry fruit treated with SA at 1000 and $2000 \mu \mathrm{mol} \mathrm{l} \mathrm{l}^{-1}$ for $5 \mathrm{~min}$, stored at $4^{\circ} \mathrm{C}$ [125], while in cherries, the response was cultivar specific, i.e. in cv. Cristalina dipped in SA at $1000 \mu \mathrm{mol} \mathrm{l}{ }^{-1}$ for $10 \mathrm{~min}$ total phenolics content was initially increased, but then no significant difference was observed between treated and untreated samples until the $20^{\text {th }}$ day of storage. In contrast, in cv. Prime Giant, total phenolics content was lower in SA treated samples during 10 days of storage at $2{ }^{\circ} \mathrm{C}$, but due to continuous increase in SA treated samples, and a decline in control during storage, it was significantly higher after 15 and 20 days of storage, respectively [42], suggesting delayed ripening early in the storage and delayed senescence later in the storage. Similarly, the increase in phenolic content was delayed in blueberries treated with $\mathrm{MeJA}$ at $50 \mu \mathrm{mol} \mathrm{l} \mathrm{l}^{-1}$ stored at $1{ }^{\circ} \mathrm{C}$; however the loss of phenolics later in the storage was reduced [124].

Higher phenolic content was also observed in loquat treated with MeJA at $10 \mathrm{mmol} \mathrm{l}^{-1}$ for $24 \mathrm{~h}$, stored at $1{ }^{\circ} \mathrm{C}$ [17] and $20^{\circ} \mathrm{C}$ [52], mangos treated with SA at $1000 \mu \mathrm{mol} \mathrm{l} \mathrm{l}^{-1}$ for $2 \mathrm{~min}$, stored at $13^{\circ} \mathrm{C}$ [61] and pomegranates treated with ASA at $100-1000 \mu \mathrm{mol} \mathrm{l} \mathrm{l}^{-1}$ for $10 \mathrm{~min}$, stored at $2{ }^{\circ} \mathrm{C}$ [13]. Total phenolic content was also reported to be higher in peaches treated with $\mathrm{MeJA}$ at $1 \mu \mathrm{mol} \mathrm{l}^{-1}[47,48,63]$ stored at $0{ }^{\circ} \mathrm{C}$, but not in their 
counterparts treated with MeJA at $100 \mu \mathrm{mol} \mathrm{l}^{-1}$ and stored at $5{ }^{\circ} \mathrm{C}$ [8]. The different response could be due to different dose of MeJA being used, different storage temperature, cultivar and maturity stage, which would all affect storability of the produce.

On the other hand, no significant effect on phenolics content was observed in MeJA treated guava [92] and SA treated pineapple [126]. Even though majority of studies reported an increase in phenolics content in response to jasmonates and salicylates, the possibility of negative results or lack of effect being not reported cannot be excluded.

\section{The use of jasmonates and salicylates in combination with other treatments}

It is apparent from this review that some commodities can benefit from jasmonates and salicylates treatment prior to storage, especially chilling sensitive ones. It has recently been demonstrated in a number of studies that the combination of different postharvest treatments may give more benefits to the produce than using a single technique alone, and a few examples are given below.

Heat treatment

Even though internal browning was reduced in peaches treated with MeJA at $1 \mu \mathrm{mol} \mathrm{l}^{-1}$ for 24 h stored at $0{ }^{\circ} \mathrm{C}$ [48] and in loquat treated with MeJA at $16 \mu \mathrm{mol} \mathrm{l}^{-1}$ for $6 \mathrm{~h}$, subsequently stored at $1^{\circ} \mathrm{C}$ [36], both studies found that combination of MeJA with hot air at $38^{\circ} \mathrm{C}$ reduced symptoms of internal browning further. Similarly, internal browning in peaches was reduced more, if the produce was heat treated at $38{ }^{\circ} \mathrm{C}$ for $12 \mathrm{~h}$ before being treated with SA at $1000 \mu \mathrm{mol} \mathrm{l}^{-1}$ for $5 \mathrm{~min}$ and stored at $0^{\circ} \mathrm{C}$ [94]. On the other hand, combination of SA and heat treatment $\left(45^{\circ} \mathrm{C}\right)$ had no significant effect on visual and textural quality of strawberries stored at $2{ }^{\circ} \mathrm{C}$ [38], but vitamin $\mathrm{C}$ content was increased in the combined treatment.

\section{Ultrasound treatment}

In another study, it has been demonstrated that fungal decay was reduced in peaches dipped in SA at $50 \mu$ mol l-1 for 10 min stored at $20^{\circ} \mathrm{C}$ [53] if combined with ultrasound treatment (40 kHz, $350 \mathrm{~W}$ ). The benefit of combined treatment was associated with increased activity of defence related enzymes, i.e. chitinase, $\beta$-1,3glucanase and PAL. In more recent study [128], combination of ultrasound (40 kHz, $350 \mathrm{~W}$ ) and SA at 1000 $\mu \mathrm{mol} \mathrm{l}^{-1}$ for 10 min was more effective in alleviating $\mathrm{CI}$ in peach fruit stored at $1{ }^{\circ} \mathrm{C}$ than the individual application of SA due to increased activity of antioxidant enzymes, e.g. CAT and APX.

\section{Interaction with other hormones}

Plant hormones, i.e. jasmonates, salicylates and ethylene are well-known for being involved in regulating multiple signalling pathways in response to stress. This makes the interpretation of reported results complicated, 
since these compounds may interact with each other in synergistic and antagonistic way. They also interact with a number of other molecules in plant cells, e.g. ROS, kinases, transcription factors, etc. More information regarding the complexity of jasmonates and salicylates can be found elsewhere [70, 123, 129-131] and is beyond the scope of this review.

\section{Conclusions}

Postharvest treatments with jasmonates and salicylates have the ability to reduce decay by increasing fruit resistance to diseases and reducing chilling injury in numerous products. These treatments also possess the ability to affect fruit ripening and improve other quality characteristics, i.e. appearance, texture maintenance and nutritional content. Furthermore, they can be easily combined with other treatments, e.g. heat treatment, ultrasound treatment. Thus, postharvest treatments with jasmonates and salicylates could be a promising and innovative tool to extend the storability of fruit by priming them, i.e. increasing their ability to withstand postharvest stresses, by accelerating their responses to attack by fungal pathogens, and increasing their resistance to chilling injury. Positive responses are often associated with increased activity of defence related enzymes and increased content of bioactive compounds. The responses, however, seem to be commodity and cultivar specific, and they also depend on other factors, such as the developmental stage of the fruit, treatment dose and subsequent storage conditions.

Acknowledgements We thank University of Greenwich for the financial support.

Conflict of Interest The authors declare that they have no conflict of interest.

\section{References}

1. Nunes MCN, Emond JP, Rauth M, Dea S, Chau, KV (2009) Postharvest Biol Technol 51:232-241

2. Ramos B, Miller FA, Brandao TRS, Silva CLM (2013) Innovative Food Sci Emerg Technol 20:409-419

3. Miller FA, Silva CLM, Brandao TRS (2013) Food Eng Rev 5:77-106

4. Glowacz M, Colgan R, Rees D (2015) J Sci Food Agric 95:662-671

5. Oms-Oliu G, Rojas-Grau MA, Gonzalez LA, Varela P, Soliva-Fortuny R, Hernando MIH, Munuera IP, Fiszman S, Martin-Belloso O (2010) Postharvest Biol Technol 57:139-148

6. Watkins CB (2006) Biotech Adv 24:389-409

7. Watkins CB (2008) HortScience 43:86-94

8. Meng X, Han J, Wang Q, Tian S (2009) Food Chem 114:1028-1035

9. Cai Y, Cao S, Yang Z, Zheng Y (2011) Postharvest Biol Technol 59:324-326

10. Cao S, Cai Y, Yang Z, Zheng Y (2012) Food Chem 133:1466-1470 
11. Cao S, Zheng Y, Wang K, Rui H, Tang S (2010) Food Chem 118:641-647

12. Sayyari M, Babalar M, Kalantari S, Martinez-Romero D, Guillen F, Serrano M, Valero D (2011) Food Chem 124:964-970

13. Sayyari M, Castillo S, Valero D, Diaz-Mula HM, Serrano M (2011) Postharvest Biol Technol 60:136-142 14. Zhang X, Shen L, Li F, Meng D, Sheng J (2011) J Agric Food Chem 59:9351-9357

15. Sevillano L, Sanchez-Ballesta MT, Romojaro F, Flores FB (2009) J Sci Food Agric 89:555-573

16. Cao S, Zheng Y, Wang K, Jin P, Rui H (2009) Food Chem 115:1458-1463

17. Cao S, Zheng Y, Yang Z, Wang K, Rui H (2009) J Sci Food Agric 89:2064-2070

18. Wang K, Jin P, Cao S, Shang H, Yang Z, Zheng Y (2009) J Agric Food Chem 57:5809-5815

19. Droby S, Porat R, Cohen L, Weiss B, Shapiro B, Philosoph-Hadas S, Meir S (1999) J Am Soc Hortic Sci 124:184-188

20. Huang RH, Liu JH, Lu YM, Xia RX (2008) Postharvest Biol Technol 47:168-175

21. Glowacz M, Mogren LM, Reade JPH, Cobb AH, Monaghan JM (2013) Postharvest Biol Technol 81:23-28

22. Ayala-Zavala JF, Wang SY, Wang CY, Gonzalez-Aguilar GA (2005) Eur Food Res Technol 221:731-738

23. Srivastava MK, Dwivedi UN (2000) Plant Sci 158:87-96

24. Luo Z, Chen C, Xie J (2011) Postharvest Biol Technol 62:115-120

25. Mo Y, Gong D, Liang G, Han R, Xie J, Li W (2008) J Sci Food Agric 88:2693-2699

26. Gonzalez-Aguilar GA, Fortiz J, Cruz R, Baez R, Wang CY (2000) J Agric Food Chem 48:515-519

27. Gonzalez-Aguilar GA, Buta JG, Wang CY (2003) Postharvest Biol Technol 28:361-370

28. Wang CY (2003) Int J Food Sci Technol 38:869-875

29. Ding CK, Wang CY (2003) Plant Sci 164:589-596

30. Oms-Oliu G, Hertog MLATM, Van de Poel B, Ampofo-Asiama J, Geeraerd AH, Nicolai BM (2011)

Postharvest Biol Technol 62:7-16

31. Van de Poel B, Bulens I, Hertog MLATM, Van Gastel L, De Proft MP, Nicolai BM, Geeraerd AH (2012)

Postharvest Biol Technol 67:59-67

32. Leslie CA, Romani RJ (1988) Plant Physiol 88:833-837

33. Zhang Y, Chen K, Zhang S, Ferguson I (2003) Postharvest Biol Technol 28:67-74

34. Yin X, Zhang Y, Zhang B, Yang S, Shi Y, Ferguson IB, Chen K (2013) Postharvest Biol Technol 83:27-33

35. Babalar M, Asghari M, Talaei A, Khosroshahi A (2007) Food Chem 105:449-453

36. Jin P, Duan Y, Wang L, Wang J, Zheng Y (2014) Food Bioprocess Technol 7:2259-2266 
37. Tareen MJ, Abbasi NA, Hafiz IA (2012) Sci Hort 142, 221-228

38. Shafiee M, Taghavi TS, Babalar M (2010) Sci Hort 124:40-45

39. Rao TVR, Gol NB, Shah KK (2011) Sci Hort 132:18-26

40. Gonzalez-Aguilar GA, Buta JG, Wang CY (2001) J Sci Food Agric 81:1244-1249

41. Tzortzakis NG, Economakis CD (2007) J Food Qual 30:567-580

42. Valero D, Diaz-Mula HM, Zapata PJ, Castillo S, Guillen F, Martinez-Romero D, Serrano M (2011) J Agric Food Chem 59:5483-5489

43. Ding ZS, Tian SP, Zheng XL, Zhou ZW, Xu Y (2007) Physiol Plant 130:112-121

44. Han J, Tian SP, Meng XH, Ding ZS (2006) Physiol Plant 128:125-133

45. Baltazar A, Espina-Lucero J, Ramos-Torres I, Gonzalez-Aguilar G (2007) J Food Eng 80:1086-1095

46. Zhang H, Ma L, Turner M, Xu H, Dong Y, Jiang S (2009) Food Chem 117:621-626

47. Jin P, Wang K, Shang H, Tong J, Zheng Y (2009) J Sci Food Agric 89:1690-1696

48. Jin P, Zheng Y, Tang S, Rui H, Wang CY (2009) Postharvest Biol Technol 52:24-29

49. Wang L, Chen S, Kong W, Li S, Archbold DD (2006) Postharvest Biol Technol 41:244-251

50. Cao S, Zheng Y, Yang Z, Tang S, Jin P (2008) J Sci Food Agric 88:1598-1602

51. Cai C, Li X, Chen KS (2006) Eur Food Res Technol 223:533-539

52. Cao S, Zheng Y, Yang Z, Tang S, Jin P, Wang K, Wang X (2008) Postharvest Biol Technol 49:301-307

53. Yang Z, Cao S, Cai Y, Zheng Y (2011) Innovative Food Sci Emerg Technol 12:310-314

54. Brummell DA, Dal Cin V, Lurie S, Crisosto CH, Labavitch JM (2004) J Exp Bot 55:2041-2052

55. Zhou HW, Ben-Arie R, Lurie S (2000) Phytochem 55:191-195

56. Jin P, Zhu H, Wang J, Chen J, Wang X, Zheng Y (2013) J Sci Food Agric 93:1827-1832

57. Chanjirakul K, Wang SY, Wang CY, Siriphanich J (2007) J Sci Food Agric 87:1463-1472

58. Wang K, Jin P, Han L, Shang H, Tang S, Rui H, Duan Y, Kong F, Kai X, Zheng Y (2014) Postharvest Biol Technol 98:90-97

59. Chanjirakul K, Wang SY, Wang CY, Siriphanich J (2006) Postharvest Biol Technol 40:106-115

60. Cao S, Cai Y, Yang Z, Joyce DC, Zheng Y (2014) Food Chem 145:86-89

61. Zeng KF, Cao JK, Jiang WB (2006) J Sci Food Agric 86:694-698

62. Yao HJ, Tian SP (2005) J Appl Microbiol 98:941-950

63. Jin P, Zheng Y, Tang S, Rui H, Wang CY (2009) J Sci Food Agric 89:802-808

64. Guo J, Fang W, Lu H, Zhu R, Lu L, Zheng X, Yu T (2014) Postharvest Biol Technol 88:72-78 
65. Moscoso-Ramirez PA, Palou L (2013) Postharvest Biol Technol 85:132-135

66. Yu T, Chen JS, Chen RL, Huang B, Liu DH, Zheng XD (2007) Int J Food Microbiol 116:339-45

67. Yu T, Zheng XD (2006) J Plant Growth Regul 25:166-174

68. Lorenzo O, Piqueras R, Sanchez-Serrano JJ, Solano R (2003) Plant Cell 15:165-178

69. Glazebrook J (2005) Annu Rev Phytopathol 43:205-27

70. Bari R, Jones JDG (2009) Plant Mol Biol 69:473-488

71. Mukkun L, Singh Z (2009) Sci Hort 123:5-10

72. Wasternack C (2014) Biotech Adv 32:31-39

73. Porat R, Weiss B, Cohen L, Daus A, Goren R, Droby S (1999) Postharvest Biol Technol 15:155-163

74. Kunkel BN, Brooks DM (2002) Curr Opin Plant Biol 5:325-331

75. Zhang H, Ma L, Turner M, Xu H, Zheng X, Dong Y, Jiang S (2010) Food Chem 122:577-583

76. Ding CK, Wang CY, Gross KC, Smith DL (2001) Plant Sci 161:1153-1159

77. Ding CK, Wang CY, Gross KC, Kenneth CS, David L (2002) Planta 214:895-901

78. Yu M, Shen L, Fan B, Zhao D, Zhen Y, Sheng J (2009) Postharvest Biol Technol 54:153-158

79. Tzortzakis NG (2007) Crop Prot 26:1507-1513

80. Yu M, Shen L, Zhang A, Sheng J (2011) J Plant Physiol 168:1820-1827

81. Chen J, Zou X, Liu Q, Wang F, Feng W, Wan N (2014) Crop Prot 56:31-36

82. Xu X, Tian S (2008) Postharvest Biol Technol 49:379-385

83. Wang K, Liao Y, Kan J, Han L, Zheng Y (2015) Int J Food Microbiol 194:32-39

84. Jiang L, Jin P, Wang L, Yu X, Wang H, Zheng Y (2015) Sci Hort 192:218-223

85. Zhu Z, Tian S (2012) Sci Hort 142:38-43

86. Conrath U, Pieterse CMJ, Mauch-Mani B (2002) Trends Plant Sci 7:210-216

87. Conrath U (2011) Trends Plant Sci 16:524-531

88. Worrall D, Holroyd GH, Moore JP, Glowacz M, Croft P, Taylor JE, Paul ND, Roberts MR (2012) New Phytol 193:770-778

89. Mauch F, Mauch-Mani B, Boller T (1988) Plant Physiol 88:936-942

90. Dixon RA, Paiva NL (1995) Plant Cell 7:1085-1097

91. Passardi F, Penel C, Dunand C (2004) Trends Plant Sci 9:534-540

92. Gonzalez-Aguilar GA, Tiznado-Hernandez ME, Zavaleta-Gatica R, Martinez-Tellez MA (2004) Biochem Biophys Res Commun 313:694-701 
93. Mittler R (2002) Trends Plant Sci 7:405-410

94. Cao S, Hu Z, Zheng Y, Lu B (2010) Postharvest Biol Technol 58:93-97

95. Zhang XH, Sheng JP, Li FJ, Meng DM, Shen L (2012) Postharvest Biol Technol 64:160-167

96. Zhao ML, Wang JN, Shan W, Fan JG, Kuang JF, Wu KQ, Li XP, Chen WX, He FY, Chen JY, Lu WJ (2013) Plant Cell Environ 36:30-51

97. Cao S, Yang Z, Cai Y, Zheng Y (2011) Food Chem 127:1777-1783

98. Valero D, Martinez-Romero D, Serrano M (2002) Trends Food Sci Technol 13:228-234

99. Mirdehghan SH, Rahemi M, Martinez-Romero D, Guillen F, Valverde JM, Zapata PJ, Serrano M, Valero D (2007) Postharvest Biol Technol 44:19-25

100. Walters DR (2003) Physiol Mol Plant P 57:137-146

101. Pottosin I, Velarde-Buendia AM, Bose J, Fuglsang AT, Shabala S (2014) J Exp Bot 65:2463-2472

102. Buchanan-Wollaston V (1997) J Exp Bot 48:181-199

103. Page T, Griffiths G, Buchanan-Wollaston V (2001) Plant Physiol 125:718-727

104. Rudell DR, Mattheis JP, Fan X, Fellman JK (2002) J Am Soc Hortic Sci 127:435-441

105. Fung RWM, Wang CY, Smith DL, Gross KC, Tao Y, Tian M (2006) J Plant Physiol 163:1049-1060

106. Fung RWM, Wang CY, Smith DL, Gross KC, Tian M (2004) Plant Sci 166:711-719

107. Sayyari M, Babalar M, Kalantari S, Serrano M, Valero D (2009) Postharvest Biol Technol 53:152-154

108. Fan X, Mattheis JP, Fellman JK (1998) J Am Soc Hortic Sci 123:421-425

109. Rudell, DR, Mattheis JP (2008) Postharvest Biol Technol 47:136-140

110. Perez A, Sanz C, Richardson DG, Olias JM (1993) J Plant Growth Regul 12:163-167

111. Liu L, Wei J, Zhang M, Zhang L, Li C, Wang Q (2012) J Exp Bot 63:5751-5761

112. de la Pena Moreno F, Monagas M, Blanch GP, Bartolome B, Ruiz del Castillo M.L (2010) Eur Food Res Technol 230:989-999

113. Wang SY, Bowman L, Ding M (2008) Food Chem 107:1261-1269

114. Eggink PM, Maliepaard C, Tikunov Y, Haanstra JPW, Bovy AG, Visser RGF (2012) Food Chem 132:301310

115. Piombino P, Sinesio F, Moneta E, Cammareri M, Genovese A, Lisanti MT, Mogno MR, Peparaio M, Termolino P, Moio L, Grandillo S (2013) Food Res Int 50:409-419

116. Jetti RR, Yang E, Kurnianta A, Finn C, Qian MC (2007) J Food Sci 72:S487-496

117. Tietel Z, Plotto A, Fallik E, Lewinsohn E, Porat R (2011) J Sci Food Agric 91:14-23 
118. de la Pena Moreno F, Blanch GP, Flores G, Ruiz del Castillo ML (2010) J Sci Food Agric 90:989-994

119. Olias JM, Sanz LC, Rios JJ, Perez AG (1992) J Agric Food Chem 40:266-270

120. Kondo S, Setha S, Rudell DR, Buchanan DA, Mattheis JP (2005) Postharvest Biol Technol 36:61-68

121. Meyer AJ (2008) J Plant Physiol 165:1390-1403

122. Hernandez I, Alegre L, van Breusegem F, Munne-Bosch S (2009) Trends Plant Sci 14:125-132

123. Fujita M, Fujita Y, Noutoshi Y, Takahashi F, Narusaka Y, Yamaguchi-Shinozaki K, Shinozaki K (2006)

Curr Opin Plant Biol 9:436-442

124. Huang X, Li J, Shang H, Meng X (2015) J Sci Food Agric 95:337-343

125. Dokhanieh AY, Aghdam MS, Fard JR, Hassanpour H (2013) Sci Hort 154:31-36

126. Lu X, Sun D, Li Y, Shi W, Sun G (2011) Sci Hort 130:97-101

127. Flores G, Ruiz del Castillo ML (2014) Postharvest Biol Technol 97:77-82

128. Yang Z, Cao S, Zheng Y, Jiang Y (2012) J Agric Food Chem 60:1209-1212

129. Zhao J, Davis LC, Verpoorte R (2005) Biotech Adv 23:283-333

130. Mur LAJ, Kenton P, Atzorn R, Miersch O, Wasternack C (2006) Plant Physiol 140:249-262

131. Kazan K, Manners JM (2008) Plant Physiol 146:1459-1468 